\title{
Nowe technologie w terapii logopedycznej dzieci z zaburzeniami mowy
}

New Technologies in Speech Therapy of Children with Speech Disorders

Słowa kluczowe: diagnoza i terapia logopedyczna, zaburzenia mowy, TIK (technologie informacyjno-komunikacyjne), platforma e-learningowa, nauczanie mieszane

Keywords: diagnosis and speech therapy, speech disorders, ICT (Information and Communication Technologies), e-learning platform, blended learning (b-learning)

\section{Wprowadzenie}

Postęp technologiczny spowodował powstanie nieznanych do tej pory w edukacji, w tym także w logopedii, nowych możliwości dydaktycznych. Wykorzystanie technologii informacyjno-telekomunikacyjnych - TIK (information and communication technologies - ICT) w nauczaniu dzieci wzbudza wiele emocji zarówno w środowiskach akademickich, jak i nauczycielskich. W celu lepszego poznania oddziaływania nowych technologii na ich najmłodszych użytkowników konieczne jest prowadzenie badań naukowych w tym zakresie. Zainteresowania naukowe autorki niniejszego artykułu koncentrują się na rozwoju językowym współczesnego dziecka w kontekście powszechnego dostępu do komputerów, laptopów, netbooków, tabletów, komórek i smartfonów oraz internetu.

Artykuł prezentuje częściowe wyniki badań naukowych autorki, w których wykorzystano platformę e-learningową w terapii logopedycznej dzieci z zaburzeniami mowy.

\footnotetext{
* Uniwersytet Kazimierza Wielkiego w Bydgoszczy, Wydział Pedagogiki, Katedra Pedagogiki Specjalnej i Logopedii, ul. J.K. Chodkiewicza 30, 85-064 Bydgoszcz, e-mail: j.jatkowska@ukw.edu.pl, ORCID: https://orcid.org/0000-0001-5640-1418.
} 


\section{Opinie logopedów na temat nowych technologii}

Wykorzystywanie nowych technologii w polskiej logopedii rozpoczęto w latach osiemdziesiątych XX wieku. Początkowo starano się dostosować programy z krajów wysoko rozwiniętych do specyfiki języka polskiego, na przykład Sokoban, Tetris, Games for Kids [Surowaniec, 1989; 1991; 1996], ProEuro [Juszczyk, Zając, 1997], Sound Recorder, Media Player [Siemieniecki, 1999], Speech Viewer [Szczepankowski, Lemirowski, 1998], Voice Processor, ASL-Spelling, Access Bliss, Head Master [Buczyńska, 1999a], Abracadabra, Happenings [Grycman, Smyczek, 2004; Grycman, 2009], BigTrack, HeadPointer, C12+CEye, Blinklt, Mrugomysz, Mrugopis, HeadMouse Extreme, Integra Mouse [Zielińska, 2012]. Analiza literatury specjalistycznej pozwala wywnioskować, że pionierzy korzystania z nowych technologii w logopedii starali się za ich pomocą wesprzeć osoby niesłyszące, niewidome, niepełnosprawne ruchowo i intelektualnie, u których komunikacja werbalna rozwijała się z utrudnieniami.

Również w terapii osób z afazją logopedzi dostrzegli potencjał technologii, co opisała Maria Pąchalska:

[...] po okresie wielkiego entuzjazmu w latach osiemdziesiątych, gdy wielu badaczom wydawało się, że komputer częściowo lub całkowicie wyręczy terapeutę w pracy z chorymi, nastąpiło równie przesadne ogólne rozczarowanie, które doprowadziło badaczy do spadku zainteresowania możliwościami wykorzystania komputerów osobistych dla potrzeb chorych z afazją [Pąchalska, 2003, s. 764-765].

Było to wówczas niewątpliwie związane nie tylko z małą dostępnością komputerów, ich kosztem, brakiem odpowiednich programów terapeutycznych, ale również z lękiem przed komputerem (szczególnie starszych pacjentów), który mógł nasilać izolację społeczną. Cytowana autorka zwraca jednak uwagę, że stopniowe poprawianie się możliwości komputerów oraz powstawanie coraz „przyjaźniejszego” oprogramowania może w przyszłości znacznie ułatwić funkcjonowanie pacjentów z afazją [Pąchalska, 2003; 2005].

Pod koniec lat osiemdziesiątych XX wieku przyszedł też czas tworzenia w środowiskach logopedycznych własnego oprogramowania, dostosowanego do specyfiki języka polskiego. Od 1988 do 2016 roku powstało w polskiej logopedii bardzo dużo programów komputerowych do terapii różnych zaburzeń mowy i ciągle tworzy się nowe. Nie sposób opisać ich wszystkich w prezentowanym artykule, dlatego w Tabeli 1 pokazano te najczęściej opisywane w literaturze przedmiotu [Surowaniec, 1995; Juszczyk, Zając, 1997; Szczepankowski, Lemirowski, 1998; Buczyńska, 1999b; Walencik-Topiłko, Miklaszewska, 2000; Gruba, 2004; 2007; Walencik-Topiłko, Bąk, 2004; Walencik-Topiłko, 2005; Kaczorowska-Bray, Miklaszewska, 2006; Ożdżyński, 2007; Szady, 2012; Waligóra-Huk, 2015]. 
Tabela 1. Polskie programy komputerowe najczęściej opisywane w literaturze przedmiotu

\begin{tabular}{|c|c|c|c|}
\hline Lp. & Data powstania programu & Nazwa programu & Autor lub producent programu \\
\hline 1 & $1988-1990$ & $\begin{array}{l}\text { Logoped: LogDgn } \\
\text { i LogTerap }\end{array}$ & $\begin{array}{l}\text { Józef Surowaniec, Barbara } \\
\text { Kędzierska, Anna Mieszkowska }\end{array}$ \\
\hline 2 & 1991-1992 & Sfonem & $\begin{array}{l}\text { Marek Iwanowski, Bronisław } \\
\text { Rocławski, Zakład Logopedii UG, } \\
\text { Young Digital Poland }\end{array}$ \\
\hline 3 & 1992 & $\begin{array}{l}\text { Logo-Gry } \\
\text { Echokorektor }\end{array}$ & Young Digital Poland \\
\hline 7 & 1992-1995 & Literki-Cyferki & Wydawnictwo Informatyczne VIPS \\
\hline 4 & 1993 & Mówiące obrazki & Young Digital Poland \\
\hline 9 & 1993-1995 & Ortomania & TimSoft \\
\hline 8 & 1994 & Mała ortografia & Wydawnictwo Informatyczne VIPS \\
\hline 5 & 1995 & Brzdąc & TimSoft \\
\hline 6 & 1995 & Softeczki & IPS Computer Group \\
\hline 10 & 1997 & $\begin{array}{l}\text { Multimedialny świat Jana } \\
\text { Brzechwy }\end{array}$ & Young Digital Poland \\
\hline 11 & 1997 & $\begin{array}{l}\text { Multimedialny świat } \\
\text { Juliana Tuwima }\end{array}$ & Young Digital Poland \\
\hline 12 & 1999 & Mówię & $\begin{array}{l}\text { Instytut Fizjologii i Patologii Słuchu } \\
\text { w Warszawie, Katedra Inżynierii } \\
\text { Dźwięku Politechniki Gdańskiej }\end{array}$ \\
\hline 13 & $2003-2004$ & $\begin{array}{l}\text { Multimedialny Pakiet } \\
\text { Logopedyczny }\end{array}$ & Komlogo \\
\hline 14 & 2004 & Czytam i piszę & $\begin{array}{l}\text { Anna Walencik-Topiłko, Young Digital } \\
\text { Poland }\end{array}$ \\
\hline 15 & 2005 & Edusensus Logopedia & Young Digital Poland \\
\hline 16 & 2005 & Abecadło i Alfabet & Aidem Media \\
\hline 17 & 2005 & $\begin{array}{l}\text { Loguś - komputerowe gry } \\
\text { logopedyczne }\end{array}$ & $\begin{array}{l}\text { Adeg.net przy współpracy } \\
\text { z Ośrodkiem Szkolno- } \\
\text { Wychowawczym dla Dzieci } \\
\text { Niesłyszących i Słabosłyszących } \\
\text { w Bydgoszczy }\end{array}$ \\
\hline 18 & 2008 & $\begin{array}{l}\text { Logorytmika. Słowa, } \\
\text { dźwięki i piosenki }\end{array}$ & $\begin{array}{l}\text { Anna Walencik-Topiłko, Young Digital } \\
\text { Planet }\end{array}$ \\
\hline 19 & 2010 & Eduterapeutica logopedia & Eduterapeutica, PWN \\
\hline 20 & 2011 & $\begin{array}{l}\text { Wspomaganie rozwoju } \\
\text { - zTosią przez pory roku } \\
\text { i Wspomaganie rozwoju- } \\
\text { Tosia i przyjaciele }\end{array}$ & $\begin{array}{l}\text { Katarzyna Szady, Young Digital } \\
\text { Planet }\end{array}$ \\
\hline
\end{tabular}

Źródło: opracowanie własne.

Wraz z rozwojem internetu rozpoczęła się era udostępniania programów logopedycznych w sieci. Pierwsza polska platforma e-learningowa do terapii logopedycznej 
- www.elogo.edu.pl - została uruchomiona w 2010 roku$^{1}$. W kolejnych latach powstały: platforma www.toker.com.pl oraz portale www.wymowapolska.pl, www .mimowa.pl, www.ktotomowi.pl, www.czytampisze.pl, www.e-terapie.pl. Oprócz platform i portali logopedycznych w latach 2009-2014 pojawiły się w sieci logopedyczne usługi on-line. Na stronach: www.s-mile.pl, www.abcpoprawnejwymowy.pl, www.polskilogopeda.com i www.logopasja.pl logopedzi udzielali porad i konsultacji oraz prowadzili zdalną terapię za pomocą aplikacji Skype i Hangouts.

Dynamika rozwoju polskich programów i aplikacji logopedycznych w ciągu ostatnich trzydziestu lat pokazała duże zainteresowanie logopedów nowymi technologiami. Warto jednak przypomnieć, że nie zawsze tak było i wiele czynników wpływało na tę sytuację. Do tej pory wykonano w Polsce zaledwie kilka badań ankietowych i sondażowych, w których przeanalizowano opinie logopedów na temat technologii informacyjno-komunikacyjnych.

Pierwsze ankiety wśród logopedów przeprowadzono w 1999 roku, a następne w 2008 roku i dokonano ich porównania. Działania te opisała Joanna Gruba w książce Technologia informacyjna w logopedii [Gruba, 2009]. Badania miały charakter porównawczy. Autorka zauważyła, że początkowe opinie logopedów na temat nowych technologii były obojętne, a nawet niechętne. W 1999 roku spośród 106 ankietowanych logopedów tylko 25 osób korzystało z komputera podczas zajęć, co stanowiło 23,6\% ankietowanych. W 2008 roku już 89,6\% logopedów używało komputerów podczas terapii (208 na 232 ankietowanych). Niewątpliwie zmiany te były związane nie tylko z pojawianiem się komputerów w gabinetach logopedycznych, ale również z coraz atrakcyjniejszymi programami do terapii logopedycznej.

Stosunek logopedów do programów komputerowych był przedmiotem zainteresowania firmy Young Digital Planet, która w 2009 roku zleciła Pracowni Badań Społecznych DGA ogólnopolskie badania telefoniczne w grupie trzystu terapeutów: logopedów i pedagogów. Wyniki pokazały, że $70 \%$ ankietowanych wykorzystywało gry i programy komputerowe podczas zajęć terapeutycznych, a szczególnie aktywni w tym zakresie byli logopedzi [Domaradzka-Grochowalska, Zielińska, 2011].

Interesujące wyniki badań przeprowadzonych w 2015 roku w ramach pogłębionych i indywidualnych wywiadów z nauczycielami-logopedami opisała Anna Waligóra-Huk w artykule Programy multimedialne jako narzędzia wykorzystywane przez nauczycieli w terapii logopedycznej [Waligóra-Huk, 2015]. Celem badań było poznanie opinii logopedów na temat wykorzystywania programów multimedialnych w pracy z uczniem z wadą wymowy. Autorka zastosowała autorski kwestionariusz wywiadu, skorzystała

1 Autorka niniejszego artykułu została w 2010 roku kierownikiem projektu unijnego „Stworzenie internetowego serwisu E-Logo-Edukacja opartego na innowacyjnych e-usługach: e-logopedia i e-statystyka". Jego celem było utworzenie pierwszej w Polsce logopedycznej platformy e-learningowej do terapii dzieci z wadami wymowy - www.elogo.edu.pl. Koncepcja powstania platformy i wykorzystania jej w badaniach naukowych została opisana w artykułach i książce [Jatkowska, Kaszubowski, 2012; Jatkowska, Hennig, 2013; Jatkowska, 2014; 2018; 2019]. 
także z techniki obserwacji logopedy w trakcie pracy terapeutycznej z dzieckiem. W badaniach wzięło udział 21 logopedów pracujących w losowo dobranych do badań szkołach podstawowych województwa śląskiego. Zebrany materiał pozwolił ustalić, że tylko $66,7 \%$ ankietowanych logopedów wykorzystywało specjalistyczne programy multimedialne w swoich gabinetach. Pozostała grupa nie miała dostępu do nowoczesnych technologii, głównie z powodu sytuacji finansowej placówki i braku środków na ich zakup. Wyniki ankiet pokazały, że badana grupa logopedów nie wskazała żadnych ujemnych stron dotyczących wykorzystywania programów komputerowych w terapii logopedycznej oprócz kwestii finansowej, związanej z kosztami ich zakupu [Waligóra-Huk, 2015].

\section{Badania własne}

W latach 2011-1013 autorka prezentowanego artykułu przeprowadziła w placówkach oświatowych na terenie Tczewa badania pilotażowe ${ }^{2}$, w których wykorzystano do terapii logopedycznej dzieci platformę e-learningową www.elogo.edu.pl. Wytypowane dzieci poddano logopedycznym badaniom diagnostycznym wstępnym, kontrolnym i końcowym. Następnie dzieci uczestniczyły w tradycyjnej terapii logopedycznej na terenie Poradni Psychologiczno-Pedagogicznej w Tczewie oraz korzystały z logopedycznej platformy e-learningowej w domu, realizując nową metodę nazwaną b-learningiem ${ }^{3}$.

Wybrano dzieci w wieku od 4 do 9 lat $\mathrm{z}$ następującymi zaburzeniami mowy: dyslalią jednoraką, dyslalią wieloraką, dyslalią całkowitą, oligofazją, dysglosją audiogenną, dysglosją uwarunkowaną rozszczepem ${ }^{4}$. Istotnym i niezmiennym założeniem badań było również to, by wybrane dzieci były prowadzone przez jednego logopedę i w tej samej placówce. Niejednolite oddziaływania logopedyczne, na przykład stosowanie różnych metod terapeutycznych lub częstotliwości spotkań, mogły wpłynąć na rzetelność badań, dlatego autorka prezentowanego artykułu osobiście poprowadziła wszystkie diagnozy oraz terapię logopedyczną wytypowanych dzieci.

W badaniach pilotażowych uczestniczyło 52 dzieci: 20 dziewczynek i 32 chłopców, jednak ich przebieg wpłynął na liczebność grupy. Z powodu kilku czynników 6 dzieci $(11,53 \%)$ przerwało realizację b-learningu. Powody rezygnacji zestawiono w Tabeli 2.

2 Badania pilotażowe stanowiły wstęp do eksperymentu pedagogicznego, który przeprowadzono w kolejnych latach, a szczegółowy opis uzyskanych wyników badań znajdzie czytelnik w cytowanej już książce B-learning $w$ diagnozie i terapii logopedycznej dzieci [Jatkowska, 2019].

3 „B-learning w terapii logopedycznej to połączenie dwóch metod - tradycyjnej, związanej z bezpośrednim kontaktem logopedy z pacjentem, $\mathrm{z}$ informatyczną, wykorzystującą nowoczesne technologie informacyjno-telekomunikacyjne (TIK). Scalenie tych metod to proces zaplanowany przez logopedę, polegający na ich wzajemnym uzupełnianiu oraz przemyślanym przechodzeniu od jednej do drugiej - aż do uzyskania sukcesu terapeutycznego" [Jatkowska, 2019, s. 110].

4 Zastosowano klasyfikację objawową Leona Kaczmarka [1977, s. 102]. 
Tabela 2. Powody rezygnacji z b-learningu

\begin{tabular}{|c|l|l|l|l|}
\hline Lp. & Imię dziecka & Wiek dziecka & $\begin{array}{c}\text { Czas } \\
\text { korzystania } \\
\text { z platformy }\end{array}$ & \multicolumn{1}{|c|}{ Powód rezygnacji } \\
\hline 1 & Julian & $\begin{array}{l}4 \text { lata } \\
\text { i } 11 \text { miesięcy }\end{array}$ & 4 miesiące & Przewlekła choroba dziecka \\
\hline 2 & Michał & $\begin{array}{l}8 \text { lat } \\
\text { i } 4 \text { miesiące }\end{array}$ & 1,5 miesiąca & $\begin{array}{l}\text { Trudności techniczne związane ze zbyt wolnym } \\
\text { łączem internetowym w domu }\end{array}$ \\
\hline 3 & Magdalena & 5 lat & 0,5 miesiąca & $\begin{array}{l}\text { Trudności techniczne związane z niskimi } \\
\text { umiejętnościami informatycznymi rodzica }\end{array}$ \\
\hline 4 & Zofia & $\begin{array}{l}3 \text { lata } \\
\text { i } 9 \text { miesięcy }\end{array}$ & 1 miesiąc & $\begin{array}{l}\text { Dziecko miało trudności ze skupieniem się } \\
\text { na ćwiczeniach on-line }\end{array}$ \\
\hline 5 & Marika & $\begin{array}{l}4 \text { lata } \\
\text { i } 8 \text { miesięcy }\end{array}$ & 1 miesiąc & $\begin{array}{l}\text { Trudności techniczne związane ze zbyt wolnym } \\
\text { łączem internetowym w domu }\end{array}$ \\
\hline 6 & Damian & 6 lat & 2,5 miesiąca & $\begin{array}{l}\text { Trudności techniczne związane z niskimi } \\
\text { umiejętnościami informatycznymi rodzica }\end{array}$ \\
\hline
\end{tabular}

Źródło: opracowanie własne.

Badania pilotażowe pozwoliły zebrać bogaty, wstępny materiał badawczy, dotyczący między innymi: czasu trwania terapii logopedycznej dzieci oraz jej skuteczności, liczby spotkań z logopedą oraz częstotliwości logowania się dziecka na platfor$m_{i}^{5}$, a także zaangażowania rodziców w proces terapeutyczny. Pozyskany materiał badawczy ilościowy i jakościowy zakodowano oraz uporządkowano w programie Microsoft Excel, następnie poddano przekształceniom statystycznym w programie SPSS (Statistical Package for the Social Sciences), a w dalszej kolejności wykonano obliczenia i analizy.

Na potrzeby niniejszego artykułu wybrano do opisu jeden aspekt badawczy, czyli sprawdzenie, dla których zaburzeń mowy b-learning może być szczególnie skuteczny, koncentrując się głównie na postępach artykulacyjnych dzieci. Początkowo ustalono cztery poziomy skuteczności: terapia nieskuteczna (dziecko nie usprawniło wymowy trenowanych głosek), mało skuteczna (dziecko usprawniło wymowę ćwiczonych głosek na podstawowych poziomach: w sylabach i wyrazach, jednak wymaga dalszej terapii logopedycznej), średnio skuteczna (dziecko usprawniło wymowę ćwiczonych głosek na wszystkich poziomach: w sylabach, wyrazach i zdaniach, jednak wymaga dalszej kontroli rodziców, głównie w mowie spontanicznej) i bardzo skuteczna (dziecko usprawniło wymowę ćwiczonych głosek na wszystkich poziomach: w sylabach, wyrazach, zdaniach i mowie spontanicznej) oraz kategorię „terapia przerwana”. Po przeprowadzeniu badań okazało się, że żadne dziecko nie znalazło się w grupie „terapia nieskuteczna”, dlatego zrezygnowano z tego poziomu skuteczności w obliczeniach statystycznych.

5 Dzieci podczas b-learningu nagrywały swój głos, co pozwoliło zebrać bardzo bogaty materiał do analizy naukowej. 
W celu sprawdzenia rozkładu skuteczności terapii pod względem zaburzeń mowy u dzieci przeprowadzono analizę testem chi-kwadrat ${ }^{6}$, na podstawie której stwierdzono, że skuteczność terapii różniła się istotnie pod względem wad wymowy $\chi^{2}(15)=33,62 ; p<0,01 ; \eta=0,45 ; V=0,46$, gdyż dzieci ze znacznymi zaburzeniami mowy osiągnęly istotnie mniejszą skuteczność terapii. Na podstawie wyniku $\eta$ stwierdzono, że $45 \%$ zmienności w zakresie zaburzeń mowy było wyjaśniane przez zmienność w zakresie skuteczności terapii. Związek tych zmiennych był umiarkowany. Wyniki analiz statystycznych przedstawia Tabela 3 oraz Wykres 1.

Tabela 3. Tabela krzyżowa dla zaburzeń mowy i skuteczności b-learningu

\begin{tabular}{|c|c|c|c|c|c|c|}
\hline & & & \multicolumn{4}{|c|}{ Skuteczność } \\
\hline & & & \begin{tabular}{|c|} 
Terapia \\
przerwa- \\
na \\
\end{tabular} & $\begin{array}{c}\text { Mało } \\
\text { skutecz- } \\
\text { na }\end{array}$ & $\begin{array}{c}\text { Średnio } \\
\text { skutecz- } \\
\text { na }\end{array}$ & $\begin{array}{c}\text { Bardzo } \\
\text { skutecz- } \\
\text { na }\end{array}$ \\
\hline \multirow{12}{*}{$\begin{array}{l}\text { Zaburzenie } \\
\text { mowy }\end{array}$} & \multirow{2}{*}{$\begin{array}{l}\text { Dyslalia } \\
\text { jednoraka }\end{array}$} & Liczebność & 0 & 0 & 4 & 3 \\
\hline & & $\%$ z zaburzeniem mowy & 0 & 0 & 57 & 43 \\
\hline & \multirow{2}{*}{$\begin{array}{l}\text { Dyslalia } \\
\text { wieloraka }\end{array}$} & Liczebność & 5 & 6 & 20 & 7 \\
\hline & & $\%$ z zaburzeniem mowy & 13 & 16 & 53 & 18 \\
\hline & \multirow{2}{*}{$\begin{array}{l}\text { Dyslalia } \\
\text { całkowita }\end{array}$} & Liczebność & 0 & 1 & 0 & 0 \\
\hline & & \% z zaburzeniem mowy & 0 & 100 & 0 & 0 \\
\hline & \multirow{2}{*}{$\begin{array}{l}\text { Dysglosja } \\
\text { uwarunkowana } \\
\text { rozszczepem }\end{array}$} & Liczebność & 1 & 0 & 0 & 0 \\
\hline & & \% z zaburzeniem mowy & 100 & 0 & 0 & 0 \\
\hline & \multirow{2}{*}{$\begin{array}{l}\text { Dysglosja } \\
\text { audiogenna }\end{array}$} & Liczebność & 0 & 2 & 0 & 0 \\
\hline & & $\%$ z zaburzeniem mowy & 0 & 100 & 0 & 0 \\
\hline & \multirow[t]{2}{*}{ Oligofazja } & Liczebność & 0 & 3 & 0 & 0 \\
\hline & & $\%$ z zaburzeniem mowy & 0 & 100 & 0 & 0 \\
\hline
\end{tabular}

Źródło: opracowanie własne.

B-learning okazał się najskuteczniejszy w grupie dzieci ze zdiagnozowaną dyslalią jednoraką - 43\% z nich uzyskało wynik „bardzo skuteczny” i 57\% „średnio

6 Test chi-kwadrat (Pearsona) „zwany jest także testem chi-kwadrat niezależności i w standardowej wersji służy do sprawdzania, czy dwie cechy są od siebie niezależne. Obliczenie testu polega na porównaniu stwierdzonego w badaniach rozkładu częstości zajścia jakichś zdarzeń z losowym rozkładem tych częstości. Test można stosować nawet wtedy, gdy dane są zgromadzone na skali nominalnej” [Francuz, Mackiewicz, 2005, s. 412-413]. Jest to nieparametryczny test, który sprawdza hipotezę zerową, mówiącą o braku zależności zmiennych. W opisie podaje się statystykę $\chi^{2}$ oraz poziom istotności $p$. W przypadku gdy $p<0,05$, odrzuca się hipotezę zerową na korzyść hipotezy alternatywnej, mówiącejo tym, że zachodzi zależność między zmiennymi. Dodatkowo podaje się współczynnik $\eta$ (eta), który jest miarą relacji. Mówi on o tym, jaka część wariancji zmiennej niezależnej jest wyjaśniana przez zmienną zależną. Dodatkowo podaje się też współczynniki $\varphi$ (phi) lub $V$ (VCramera), które służą do pomiaru siły zależności pomiędzy dwiema zmiennymi jakościowymi mierzonymi na poziomach nominalnych ( $<0,3$ słaba, 0,3-0,5 umiarkowana, $>0,5$ silna). Współczynnik $\varphi$ jest używany w przypadku tabel $2 \times 2$, a $V$ Cramera w przypadku tabel większych [Francuz, Mackiewicz, 2005]. 
skuteczny". Na drugim miejscu znalazły się dzieci z dyslalią wieloraką. W tej grupie dla $18 \%$ badanych b-learning okazał się „bardzo skuteczny”, a dla 53\% „średnio skuteczny". Należy zauważyć, że w grupie dzieci z dyslalią wieloraką aż 13\% dzieci przerwało terapię, co niewątpliwie wpłynęło na wynik końcowy. Opisane grupy dzieci (z dyslalią jednoraką i wieloraką), które uzyskały wynik „bardzo skuteczny” i „średnio skuteczny”, stanowiły 65,38\% wszystkich badanych (34 dzieci z 52). Na tej podstawie można potwierdzić hipotezę, że b-learning okazał się metodą szczególnie skuteczną w przypadku dzieci z dyslalią jednoraką i wieloraką.

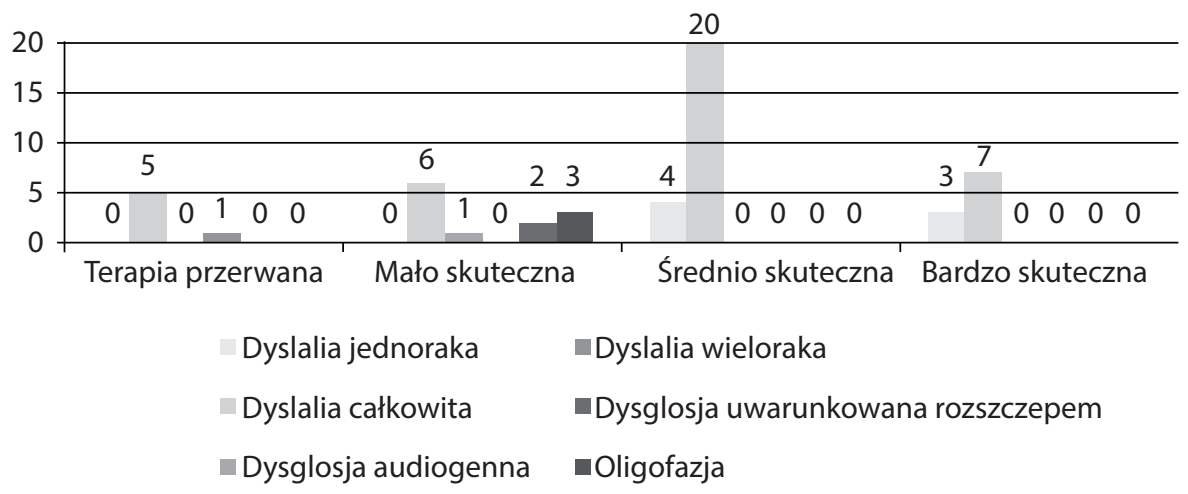

Wykres 1. Wykres rozkładu skuteczności terapii pod względem zaburzeń mowy

Źródło: opracowanie własne.

Powyższe wyniki istotnie wpłynęły na dalszy proces badania zjawiska b-learningu. Uznano bowiem, że do planowanego eksperymentu pedagogicznego wytypowane zostaną wyłącznie dzieci z dyslalią jednoraką, wieloraką i całkowitą. Przyczyny tej decyzji były dwie:

- do grupy kontrolnej znacznie łatwiej było dobrać odpowiednie pary dzieci z dyslalią jednoraką, wieloraką i całkowitą niż z dysglosją rozszczepową, dysglosją audiogenną i oligofazją;

- porównanie skuteczności b-learningu tak skrajnych grup dzieci nie byłoby rzetelne ${ }^{7}$.

\section{Zakończenie}

Zaprezentowane wyniki badań pokazały, że nowe technologie mogą przyczyniać się do rozwoju umiejętności artykulacyjnych dzieci. Zależało to oczywiście od kilku zmiennych, na przykład wyboru odpowiedniego narzędzia terapeutycznego w postaci

7 Szczegółowe wyniki eksperymentu pedagogicznego znajdzie czytelnik w książce B-learning $w$ diagnozie i terapii logopedycznej dzieci [Jatkowska, 2019]. 
platformy e-learningowej, ścisłej współpracy z rodzicami, a także nowej organizacji pracy logopedy. Opisany sukces terapeutyczny dotyczył głównie dzieci z lżejszymi wadami wymowy. Dzieci ze znacznymi zaburzeniami mowy nie odniosły spektakularnych sukcesów terapeutycznych. Niewątpliwie przyczyny można upatrywać w tym, że ćwiczenia zawarte na platformie www.elogo.edu.pl koncentrowały się głównie na aspekcie artykulacji, co w przypadku dzieci z dysglosją audiogenną, dysglosją rozszczepową czy oligofazją mogło być trudniejsze do osiągnięcia w porównaniu $\mathrm{z}$ dziećmi $\mathrm{z}$ prostymi wadami wymowy. Należy jednak podkreślić, na co zwrócili uwagę rodzice w ankietach, że terapia logopedyczna dzieci ze znacznymi zaburzeniami mowy jest zwykle długotrwała i bardzo żmudna. Wprowadzenie do domowych ćwiczeń nowych rozwiązań w postaci zabaw interaktywnych na platformie przyczyniło się nie tylko do ich uatrakcyjnienia, ale i do zwiększenia zaangażowania dzieci w trening logopedyczny. Wpłynęło to na fakt, że żadne dziecko z tej grupy nie znalazło się w kategorii „terapia nieskuteczna”.

Podczas analizy materiału badawczego zaobserwowano dodatkowe zjawiska występujące podczas realizacji b-learningu, o których warto wspomnieć.

Zwiększone zaangażowanie dzieci w proces terapii logopedycznej z powodu użycia komputera i internetu nie było stałe. Wraz z poznawaniem materiału edukacyjnego i pracy na platformie fascynacja stopniowo malała, co widać w spadku liczby logowań. Dzieci chętnie współpracowały w b-learningu około 6 miesięcy. Po tym okresie obserwowano znużenie. By podtrzymać zainteresowanie dziecka, wskazane byłoby rozbudowanie zasobów platformy o kolejne, nowe e-logolekcje ${ }^{8}$. Ma to szczególnie znaczenie w trudniejszych przypadkach zaburzeń mowy, gdy terapia się przedłuża. Dziecko potrzebuje wówczas nie dwudziestu jednostek lekcyjnych, a trzydziestu lub czterdziestu. Dlatego logopedyczne platformy e-learningowe powinny mieć bardzo bogaty materiał edukacyjny, który logopeda mógłby dodatkowo włączać do pracy $\mathrm{w}$ terapiach długoterminowych.

Badania nad b-learningiem pokazały, że może on zmniejszyć liczbę bezpośrednich spotkań logopedy z dzieckiem w poradni, zachowując skuteczność terapii, co było szczególnie istotne dla osób dojeżdżających z daleka. Jednak logopeda w b-learningu pracował nie tylko $\mathrm{w}$ gabinecie, ale również na platformie, co wiązało się $\mathrm{z}$ nową organizacją pracy. W tej sytuacji konieczne było ustalenie godzin pracy i ich rozliczania, miejsca wykonywania nowych zadań oraz sposobu dokumentowania aktywności w internecie. Są to wyzwania towarzyszące wprowadzaniu nowych rozwiązań edukacyjnych w logopedii, które niewątpliwie wymagają jeszcze dopracowania.

8 E-logolekcja to termin zaprezentowany na Ogólnopolskiej Konferencji Logopedycznej w Gdańsku „Historia, współczesność i perspektywy rozwoju polskiej logopedii” [Jatkowska, Kaszubowski, 2012]. Jest to klasyczne zajęcie logopedyczne, przełożone na interaktywne zabawy przed komputerem, w skład którego wchodzą: ćwiczenia oddechowe, słuchowe, motoryczne i artykulacyjne, a także czytania i pisania trenowanych sylab, wyrazów i zdań. Nowatorstwem e-logolekcji było zdalne nagrywanie głosu dziecka w domu. Logopeda, poprzez platformę e-learningową, miał możliwość odsłuchania tych nagrań i przeanalizowania ich [Jatkowska, 2019, s. 83]. 
Literatura

Buczyńska J., 1999a, Sprzęt komputerowy i oprogramowanie przeznaczone dla osób niepetnosprawnych, [w:] B. Siemieniecki (red.), Komputer w diagnozie i terapii pedagogicznej, Toruń: Wydawnictwo Adam Marszałek, s. 71-94.

Buczyńska J., 1999b, Komputer w praktyce logopedycznej, [w:] B. Siemieniecki (red.), Komputer $w$ diagnozie i terapii pedagogicznej, Toruń: Wydawnictwo Adam Marszałek, s. 53-69.

Domaradzka-Grochowalska Z., Zielińska M., 2011, Ryzyko dysleksji, dysleksja, wady wymowy, a współczesne możliwości technologiczne, [w:] W. Brejnak, E. Wolnicz-Pawłowska (red.), Logopedia a specjalne potrzeby edukacyjne w obliczu reformy szkolnej, Warszawa: Wydawnictwo Uniwersytetu Kardynała Stefana Wyszyńskiego, s. 139-160.

Francuz P., Mackiewicz P., 2005, Liczby nie wiedza, skąd pochodzą. Przewodnik po metodologii i statystyce nie tylko dla psychologów, Lublin: Wydawnictwo Katolickiego Uniwersytetu Lubelskiego.

Gruba J., 2004, Multimedialny pakiet logopedyczny, [w:] W. Strykowski, W. Skrzydlewski (red.), Kompetencje medialne społeczeństwa wiedzy, Poznań: Oficyna Edukacyjna Wydawnictwa eMPi2, s. 335-339.

Gruba J., 2007, Ocena programów komputerowych wspierających terapię sygmatyzmu, [w:] S. Juszczyk, M. Musioł, A. Watoła (red.), Edukacja w społeczeństwie wiedzy. Niejednoznaczność rzeczywistości edukacyjnej, społecznej i kulturowej, Katowice: Agencja Artystyczna PARA, s. 370-375.

Gruba J., 2009, Technologia informacyjna w logopedii, Gliwice: Wydawnictwo Komlogo.

Grycman M., 2009, Sprawdź, jak się porozumiewam. Ocena efektywności porozumiewania się dzieci niemówiących wraz z propozycjami strategii terapeutycznych, Kraków: Wydawnictwo i Poligrafia Kurii Prowincjonalnej Zakonu Pijarów.

Grycman M., Smyczek A. (red.), 2004, Wiem, czego chcę!, Kraków: Stowarzyszenie Mówić bez słów. Jatkowska J., 2014, B-learning w terapii logopedycznej dzieci - wyniki innowacji pedagogicznej, [w:] F. Makurat, M. Brodnicki, A. Nawrocka (red.), Wokót problemów patologii grup społecznych, Starogard Gdański: Pomorska Szkoła Wyższa w Starogardzie Gdańskim, s. $135-149$.

Jatkowska J., 2018, Rozwój językowy dziecka a b-learning, „Annales Universitatis Paedagogicae Cracoviensis. Studia de Cultura", t. 10, nr 4, s. 125-140.

Jatkowska J., 2019, B-learning w diagnozie i terapii logopedycznej dzieci, Gdańsk: Harmonia Universalis.

Jatkowska J., Hennig N., 2013, E-learning w terapii logopedycznej - wyniki badań własnych, [w:] E. Skorek, K. Kochan (red.), Wybrane zagadnienia z teorii i praktyki logopedycznej, Zielona Góra: Oficyna Wydawnicza Uniwersytetu Zielonogórskiego, s. 147-161.

Jatkowska J., Kaszubowski P., 2012, Logopedia w internecie, [w:] S. Milewski, K. Kaczorowska-Bray (red.), Logopedia. Wybrane aspekty historii, teorii i praktyki, Gdańsk: Harmonia Universalis, s. $408-415$.

Juszczyk S., Zając W., 1997, Komputerowa edukacja uczniów z zaburzeniami w czytaniu i pisaniu, Katowice: Wydawnictwo „Śląsk”.

Kaczmarek L., 1977, Nasze dziecko uczy się mówić, Lublin: Wydawnictwo Lubelskie.

Kaczorowska-Bray K., Miklaszewska A., 2006, Wykorzystanie programów komputerowych $w$ terapii logopedycznej dzieci upośledzonych umysłowo w stopniu lekkim i umiarkowanym,

[w:] S. Juszczyk, I. Polewczyk (red.), Media wobec wielorakich potrzeb dziecka, Toruń:

Wydawnictwo Adam Marszałek, s. 79-85.

Ożdżyński G., 2007, Recenzja programu LOGOPEDIA, „Logopedia”, nr 36, s. 277-280. 
Pąchalska M., 2003, Terapia chorego z afazja, [w:] T. Gałkowski, G. Jastrzębowska (red.), Logopedia - pytania i odpowiedzi. Podręcznik akademicki, t. 2, Opole: Wydawnictwo Uniwersytetu Opolskiego, s. 700-771.

Pąchalska M., 2005, Kierunki współczesnej terapii chorych z afazja, [w:] T. Gałkowski, E. Szeląg, G. Jastrzębowska (red.), Podstawy neurologopedii, Opole: Wydawnictwo Uniwersytetu Opolskiego, s. 846-906.

Siemieniecki B., 1999, Komputerowa diagnostyka i terapia pedagogiczna, [w:] B. Siemieniecki (red.), Komputer w diagnozie i terapii pedagogicznej, Toruń: Wydawnictwo Adam Marszałek, s. 9-23.

Surowaniec J., 1989, Komputer - szansa dla logopedii, „Oświata i Wychowanie”, nr 29, s. 22-25.

Surowaniec J., 1991, Technika komputerowa w zapobieganiu trudnościom w nauce czytania i pisania, „Logopedia”, nr 18, s. 119-135.

Surowaniec J., 1995, Funkcje zabaw i gier komputerowych w metodyce postępowania logopedycznego, [w:] J. Ożdżyński (red.), Językowy obraz świata dzieci i młodzieży, Kraków: Wydawnictwo Naukowe Wyższej Szkoły Pedagogicznej, s. 441-462.

Surowaniec J., 1996, Dekada informatyczna w rozwoju polskiej logopedii 1986-1996, „Logopedia”, nr 23, s. 183-189.

Szady K., 2012, Wykorzystanie autorskich programów multimedialnych w terapii logopedycznej dzieci niepetnosprawnych, [w:] S. Milewski, K. Kaczorowska-Bray (red.), Logopedia. Wybrane aspekty historii, teorii i praktyki, Gdańsk: Harmonia Universalis, s. 402-407.

Szczepankowski B., Lemirowski A., 1998, Komputer w pracy z dzieckiem z uszkodzonym stuchem, [w:] J. Łaszczyk (red.), Komputer w kształceniu specjalnym, Warszawa: Wydawnictwa Szkolne i Pedagogiczne, s. 106-126.

Walencik-Topiłko A., 2005, Wykorzystanie programów komputerowych w profilaktyce, diagnozie i terapii logopedycznej, [w:] T. Gałkowski, E. Szeląg, G. Jastrzębowska (red.), Podstawy neurologopedii. Podręcznik akademicki, Opole: Wydawnictwo Uniwersytetu Opolskiego, s. 1019-1027.

Walencik-Topiłko A., Bąk J., 2004, Multimedialny program do diagnozy i terapii logopedycznej, [w:] M. Sysło (red.), Informatyka w szkole XX, Wrocław: Stowarzyszenie Nauczycieli Technologii Informacyjnej, s. 776-779.

Walencik-Topiłko A., Miklaszewska A., 2000, Charakterystyka polskich programów komputerowych wspomagających terapię logopedyczna, [w:] E. Łuczyński (red.), Kształcenie logopedyczne - cele i formy, Gdańsk: Wydawnictwo Uniwersytetu Gdańskiego, s. 80-84.

Waligóra-Huk A., 2015, Programy multimedialne jako narzędzia wykorzystywane przez nauczycieli w terapii logopedycznej, [w:] D. Siemieniecka (red.), Edukacja a nowe technologie w kulturze, informacji i komunikacji, Toruń: Wydawnictwo Naukowe Uniwersytetu Mikołaja Kopernika, s. 343-354.

Zielińska J., 2012, Przykłady wykorzystania nowoczesnych technologii w komunikacji alternatywnej, [w:] J. Morbitzer, E. Musiał (red.), Człowiek - Media - Edukacja, Kraków: Katedra Technologii i Mediów Edukacyjnych, Uniwersytet Pedagogiczny im. KEN, s. 637-649.

\section{Streszczenie}

Polska logopedia wykorzystuje technologie informacyjno-komunikacyjne (TIK) w diagnozie i terapii od ponad trzydziestu lat. Początkowo logopedzi korzystali ze światowych aplikacji, by w latach dziewięćdziesiątych XX zacząć tworzyć własne programy komputerowe, dostosowane do specyfiki języka polskiego. Wraz z rozwojem internetu pojawiły się logopedyczne platformy e-learningowe. Jedną z nich autorka niniejszego artykułu wykorzystała w terapii 
logopedycznej dzieci z zaburzeniami mowy, by sprawdzić, czy nowe technologie mogą przyczyniać się do poprawy artykulacji. Przeprowadzony eksperyment pedagogiczny pokazał, że autorska koncepcja b-learningu może być skuteczna w terapii logopedycznej dzieci.

\section{Abstract}

Polish speech therapy has been using information and communication technologies (ICT) in diagnosis and therapy for over 30 years. Initially, speech therapists used world-wide innovations to start creating their own computer programs tailored to the specificity of the Polish language in the 1990s. Along with the development of the Internet, speech therapy platforms have emerged. One of them, the author of this article, used speech therapy in children with speech disorders to check whether new technologies can contribute to the improvement of articulation. The conducted pedagogical experiment showed that the author's concept of b-learning can be effective in speech therapy for children. 